Pesq. Vet. Bras. 37(8):874-876, agosto 2017

DOIS: $10.1590 /$ S0100-736X2017000800016

\title{
Sarcocystis spp. in red deer (Cervus elaphus), fallow deer (Dama dama), and pudu (Pudu pudu) in southern Chile ${ }^{1}$
}

\author{
Esteban Reyes Lobão-Tello² ${ }^{2}$ Enrique Paredes ${ }^{2}$ and María José Navarrete-Talloni ${ }^{*}$
}

\begin{abstract}
Reyes E., Paredes E. \& Navarrete-Talloni M.J. 2017. Sarcocystis spp. in red deer (Cervus elaphus), fallow deer (Dama dama), and pudu (Pudu pudu) in southern Chile. Pesquisa Veterinária Brasileira 37(8):874-876. Unidad de Anatomía Patológica, Instituto de Patología Animal, Facultad de Ciencias Veterinarias, Universidad Austral de Chile, Campus Isla Teja, Valdivia, Chile. E-mail: majose.navarrete@uach.cl

Worldwinde, cervids are considered an important source of infection and dissemination of a wide variety of pathogens, both for farm animals and humans. Among this diseases is sarcosporidiosis, which is a parasitic disease caused by Sarcocystis spp. (Protozoa: Apicomplexa). Most frequent clinical signs are hemolytic anemia, weakness, weight loss and decrease of growth and some species of Sarcocystis might cause abortions. The clinical disease in ruminants is fairly rare but the infection is very frequent. Infections are accumulative and the parasite does not generate immunity in any of the hosts. Ovine sarcosporidiosis is a serious issue in the some regions of Chile due to the macrocysts located in the muscle which means condemnation of the whole carcass. Sarcocystis spp. has been widely reported in red deer and other cervid species but in Chile the situation remains unknown. Nowadays there is little to no evidence of Sarcocystis in foreign deer in Chile and there is only one report of the parasite on pudu. The main goal of this study is to demonstrate the presence of Sarcocystis spp. in myocardium of red deer and fallow deer in Chile, and confirm the presence of Sarcocystis spp. in pudu. All cervid cases from 1994 to 2013 of the Institute of Animal Pathology of the Universidad Austral de Chile were reviewed. The animals selected were those in which a myocardium sample was taken. From the histopathological samples observed, it was found that 5 of the 9 red deer, 1 of the 4 fallow deer and in 11 of the 23 pudu there were Sarcocystis cysts in the myocardium. This study represents the first record for Chile of Sarcocystis spp. in myocardium of red deer and fallow deer. Stablishing the red deer, fallow deer and pudu as hosts of Sarcocystis aids to have a better understanding of the parasite epidemiology in Chile and the role of wild and captive cervids in the maintenance and spread of these parasites.
\end{abstract}

INDEX TERMS: Sarcocystis spp., red deer, Cervus elaphus, fallow deer, Dama dama, pudu, Pudu pudu, Chile.

RESUMO.- [Sarcocystis spp. em veado (Cervus elaphus), Gamo (Dama dama) e Pudu (Pudu pudu) no sul do Chile.] No mundo, os cervos são considerados uma fonte de infecção e propagação de uma grande variedade de patógenos para animais de criação e para os seres humanos. Entre estas doenças está a sarcosporidiosis, que é uma doença parasitária causada por Sarcocystis spp. (Protozoa: Apicomplexa). Os sinais clínicos mais comuns são anemia

\footnotetext{
${ }^{1}$ Received on July 18, 2016.

Accepted for publication on January 27, 2017.

${ }^{2}$ Unidad de Anatomía Patológica, Instituto de Patología Animal, Facultad de Ciencias Veterinarias, Universidad Austral de Chile, Isla Teja, Valdivia, Chile. *Corresponding author: majose.navarrete@uach.cl
}

hemolítica, fraqueza, perda de peso e diminuição do crescimento e em algumas espécies de Sarcocystis podem causar abortos. A doença clínica em ruminantes é bastante rara, mas a infecção é muito comum. As infecções são cumulativos e o parasita não gera imunidade em nenhum dos seus hospedeiros. A Sarcosporidiosis ovina é um problema grave em algumas regiões do Chile devido a microcistos localizados no músculo provocando a reprovação total da carcaça. Sarcocystis spp. tem sido amplamente relatado em cervos vermelhos e outras espécies de cervídeos, mas no Chile a sua situação permanece desconhecida. Atualmente há pouca ou nenhuma evidência de Sarcocystis em cervos introduzidos no Chile e há apenas um relatório do parasita em pudú. 0 principal objetivo deste estudo é demons- 
trar a presença de Sarcocystis spp. no miocárdio no veado vermelho e cervo gamo no Chile e confirmar a presença de Sarcocystis spp. em pudus. Revisaram-se todos os casos de cervos desde 1994-2013 do Instituto de Patologia Animal da Universidad Austral de Chile. Os animais selecionados para o estudo foram aqueles em que se tomou amostra de miocárdio. Das amostras histopatológicas observadas, verificou-se que em cinco dos nove cervos vermelhos, em um dos quatro veados gamo e 11 dos 23 pudus tinham cistos de Sarcocystis no miocárdio. Este estudo representa o primeiro relatório para o Chile de Sarcocystis spp. no miocárdio de veados vermelhos e cervo gamo. Definir o veado vermelho, o cervo gamo e os pudú como anfitriões de Sarcocystis ajuda a uma melhor compreensão da epidemiologia deste parasita no Chile e o papel de cervos selvagens e em cativeiro para a manutenção e divulgação deste parasita.

TERMOS DE INDEXAÇÃO: Sarcocystis spp., veado, Cervus elaphus,, gamo, Dama dama, pudú, Pudu pudu, Chile, cervo.

\section{INTRODUCTION}

Nowadays Chile has 7 deer species, divided in autochthonous and foreign species. Autochthonous species are the taruca (Hippocamelus antisensis), the huemul (Hippocamelus bisculus), and the pudu (Pudu pudu) (Iriarte 2008). The foreign species are axis deer (Cervus axis), European roe deer (Capreolus capreolus), red deer (Cervus elaphus), and fallow deer (Dama dama), used in the industry of venison and gaming (Iriarte 2008). Worldwinde, cervids are considered an important source of infection and dissemination of a wide variety of pathogens, both for farm animals and humans. Among this diseases is sarcosporidiosis (Böhm et al. 2007). Sarcocystis is the ethiological agent of sarcocystosis or sarcosporidiosis in different kinds of animals. Its biological cycle is indirect and is transmitted by ingestion. The definitive host is a predator, who eliminates sporulated oocyst to the environment through feces. This sporulated oocyst are ingested by a herbivore-prey intermediate host. The parasite migrates to the striated skeletal or cardiac muscle where they form cysts. The cycle continues when this cysts are eaten by the definitive host (McKenna \& Charleston 1980, Barriga 2002, Dahlgren \& Gjerde 2007). Sarcocystis have low pathogenicity for the definitive host and rarely cause disease. Nevertheless, some species are zoonotic (Barriga 2002). Evidence of gastroenteric disorders in humans who have consumed undercooked meat infected with Sarcocystis have been reported, due to toxic substances in the cysts (Sam et al. 1998). The Sarcocystis disease happens mostly in the intermediate host in severe infection cases. Most frequent clinical signs are hemolytic anemia, weakness, weight loss and decrease of growth (Barriga 2002). Some species of Sarcocystis might cause abortions (Leek \& Fayer 1978, Dubey 1981, Dubey \& Bergeron 1982). Sarcocystis is highly specific on the intermediate host, but not on the definitive host (Poli et al. 1988). Consuming high doses of sporocysts might result in clinical disease, abortions, and even death. Consuming low doses result in a decrease on weight gain and growth (Collins 1981). The clinical disease in ruminants is fairly rare but the infection is very frequent (from $60-90 \%$ in some sec- tors in Argentina) (Moré et al. 2011). This situation might be because there are at least 3 species that affect bovine and 2 for ovine (Barriga 2002). Infections are accumulative and the parasite does not generate immunity in any of the hosts (Barriga 2002). Histopathological studies show elongated cylindrical cysts located across the muscle (Gorman 1984). There are 2 kinds of Sarcocystis cysts, those with thick wall and those with thin wall, which depends on the species. Moré et al. (2011), demonstrated that thick wall cysts don't affect the myocardium. In some species like ovine and South American camelids the cysts might be macroscopic with a size of approximately $2 \mathrm{~cm}$ (Gorman 1984). Ovine sarcosporidiosis is a serious issue in the Magallanes region due to the macrocysts located in the muscle which means condemnation of the whole carcass. Sarcocystis spp. has been reported in red deer and other cervid species in Europe (Collins 1981). Nowadays there is no evidence of Sarcocystis in foreign deer in Chile. In 1976, the first report of Sarcocystis in pudu in Chile was made by Rioseco et al. (1976). In New Zealand, one third of red deer are infected with Sarcocystis (Collins 1981). This is important due to the climatological similarities between the two countries and that most foreign deer in Chile came from New Zealand. The main goal of this study is to demonstrate the presence of Sarcocystis spp. in myocardium of red deer and fallow deer, and confirm the findings of Rioseco et al. 1976 about presence of Sarcocystis spp. in pudu.

\section{MATERIALS AND METHODS}

All cervid cases from 1994 to 2013 of the Institute of Animal Pathology of the Universidad Austral de Chile were reviewed. The animals selected were those in which a myocardium sample was taken. The outcome of cases selection was 39 animals, 9 red deer, 4 fallow deer and 23 pudu. Heart samples were preserved in buffered formalin $10 \%$ and histological sections were made for subsequent staining with hematoxylin-eosin.

\section{RESULTS}

From the histopathological samples observed, it was found that 5 of the 9 red deer had Sarcocystis cysts in the myocardium, with an average of 9.4 cysts for sample. Only 1 of the 4 fallow deer had cysts ( 6 cysts). In 11 of the 23 pudu examined cysts were observed, with an average of 7.3 cysts for sample (Fig.1, Table 1).

\section{DISCUSSION}

This study represents the first record for Chile of Sarcocystis spp. in myocardium of red deer and fallow deer. The possible explanation for the presence of this protozoan in this cervids lies in the association between farmed deer and livestock of dairy cattle and sheep. It is possible that there is an interaction between deer and dogs and that the latter contributes as a reservoir for these Sarcocystis and have a significant role in transmission to wildlife and also cattle and sheep of dairy and meat farms. Cabello (2002) showed that in dogs in Valdivia there is a 3.9\% prevalence of Sarcocystis spp. and a $0.7 \%$ of Sarcocystis bovicanis. There is no current data on the situation in rural areas. But there is a high probability that the prevalence is higher due to 


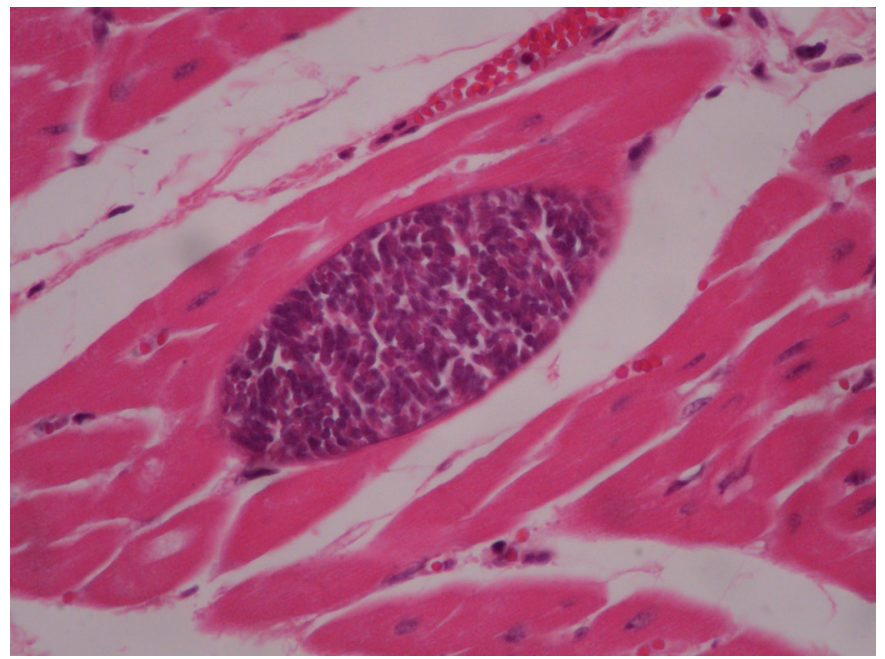

Fig.1. Sarcocystis cyst on myocardium cell, Pudu. HE, obj.40x.

Table 1. Number of Sarcocystis spp. cysts found on each positive case

\begin{tabular}{ccc}
\hline Species & Case & Number of cysts \\
\hline Red deer & 1 & 10 \\
& 2 & 7 \\
& 3 & 6 \\
& 4 & 9 \\
Fallow deer & 5 & 15 \\
Pudu & 1 & 6 \\
& 1 & 1 \\
2 & 1 \\
& 3 & 2 \\
& 4 & 1 \\
5 & 8 \\
6 & 30 \\
& 7 & 12 \\
& 8 & 14 \\
9 & 7 \\
& 10 & 2 \\
11 & 1
\end{tabular}

the frequent consumption of fresh/raw prey. The situation in countries with similar climate to the geographical zone of the study is very diverse. In Scotland has been shown a $27 \%$ prevalence of Sarcocystis in red deer. In this paper, all positive deer had cysts on the myocardium of which only 8.6\% showed signs of heart disease (Böhm et al. 2007). In Argentina, Moré et al. (2011) demonstrated in their study a prevalence of $73.1 \%$ and that $95.5 \%$ of the animals with Sarcocystis in the Province of Rio Negro had Sarcocystis cruzi in the myocardium. A third of New Zealand red deer are infected with some sort of Sarcocystis, according to the paper of Collins (1981). The determination of these protozoa species will be done by molecular tests as soon as it's possible to implement the technique. In the world, it has been able to identify many species that affect different cervids. Dahlgren \& Gjerde (2007), were able to isolate at least 5 different species of Sarcocystis in cervids. Has been demonstrated that several species of Sarcocystis may be parasitizing simultaneously the same animal and that some of them can develop in various definitive hosts (Cordero del Campillo et al. 1999). In Chile there are no studies that support in full the possible definitive hosts per species of Sar- cocystis, but it is known that virtually any carnivore is a potential host for this parasite. Among the possible hosts we found the dog, cat, fox and several wild cats. In the study of Holsback et al. (2013), for example, Sarcocystis sporocysts were found in feces of cougar (Puma concolor). McKenna \& Charleston (1980) found that the prevalence of Sarcocystis spp. in dogs of semi-rural areas can be as high as 58.8\%, while cats $16.9 \%$. On several occasions, the dog has been proven to be definitive host of cysts extracted from deer, but here has been no success inoculating cats (Poli et al. 1988). Stablishing the red deer, fallow deer and pudu as hosts of Sarcocystis aids to have a better understanding of the parasite epidemiology in Chile and the role of wild and captive cervids in the maintenance and spread of these parasites. Future studies will focus on determining Sarcocystis species involved to better establish its origin and possible zoonotic capacity.

\section{REFERENCES}

Barriga 0.0. 2002. Las enfermedades parasitarias de los animales domésticos de la América Latina. Editorial Germinal. Santiago.

Böhm M., White P.C.L., Chambers J., Smith L. \& Hutchings M.R. 2007. Wild deer as a source of infection for livestock and humans in the UK. Vet. J. 174:260-276.

Cabello J. 2002. Estudio parasitario a través de muestras de materia fecal de perros (canis familiaris) provenientes de la ciudad de Valdivia, Chile. Tesis licenciatura, Escuela de Medicina Veterinaria, Universidad Austral de Chile.

Collins G.H. 1981. Studies in Sarcocystis species. VIII. Sarcocystis and Toxoplasma in red deer (Cervus elaphus). N.Z. Vet. J. 29:126-127.

Cordero del Campillo M., Rojas F., Fernandez M., Sanchez M., Rodriguez S. \& Lopez I. 1999. Prasitología veterinaria. Editorial McGraw-Hill, España.

Dahlgren S.S. \& Gjerde B. 2007. Genetic characterisation os six Sarcocystis species from reindeer (Rangifer tarandus tarandus) in Norway based on the small subunit rRNA gene. Vet. Parasithol. 146:204-213.

Dubey J.P. 1981. Abortion and death in goats inoculated with Sarcocystis sporocysts from coyote feces. J. Am. Vet. Med. Assoc. 178:700-703.

Dubey J.P. \& Bergeron J.A. 1982. Sarcocystis as a cause of placentitis and abortion in cattle. Vet. Pathol. 19:315-318.

Gorman T. 1984. Nuevos conceptos sobre sarcosporidiosis animal. Monografias Med. Vet. 6:5-23.

Holsback L., Lahm M.J., Fagnani R. \& Constantino T.H. 2013. Natural infection by endoparasites among free-living wild animals. Revta Bras. Parasitol. Vet. 22:302-306.

Iriarte A. 2008. Mamiferos de Chile. Lynx Ediciones. Barcelona, España, p.220-221.

Leek R.G. \& Fayer R. 1978. Sheep experimentally infected with Sarcocystis from dogs. II. Abortion and disease in ewes. Cornell Vet. 68:108-123.

McKenna P.B. \& Charleston W.A.G. 1980. Coccidia (protozoa: sporozoasida) of cats and dogs. IV. Identity and prevalence in dogs. N.Z. Vet. J. 28:128-130.

Moré G., Abrahamovich P., Jurado S., Bacigalupe D., Marin J.C., Rambeaud M., Venbturini L. \& Venturini M.C. 2011. Prevalence of Sarcocystis spp. in Argentinian cattle. Vet. Parasithol. 177:162-165.

Poli A., Mancianti F., Marconcini A., Nigro M. \& Colagreco R. 1988. Prevalence, ultraestructure of the cyst Wall and infectivity for the dog and cat of Sarcocystis sp. from fallow deer (Cervus dama). J. Wildl. Dis. 24:97-104.

Rioseco H., Cubillos V., González H. \& Díaz L. 1976. Sarcosporidiosis en Pudues (Pudu pudu Molina, 1782): primera comunicacion en Chile. Arch. Med. Vet. 8:122-123.

Sam R., Mansilla I., Morales C. \& Ramírez A. 1998. Efecto tóxico de macroquistes de Sarcocystis aucheniae en ratones, cobayos y conejos. Revta Invest. Pec. 9:11-18. 